\title{
SYMPTOMATIC DISCOID MENISCUS: A CASE SERIES
}

\author{
Asep Santoso $^{1}$, Erwin Saspraditya ${ }^{2}$, Muhammad Nagieb ${ }^{3}$, Gilang Persada Aribowo ${ }^{1}$, \\ Iwan Budiwan Anwar ${ }^{1}$, Tangkas SMHS Sibarani ${ }^{1}$
}

\section{${ }^{1}$ Department of Orthopaedic and Traumatology, Prof. Dr. R. Soeharso Orthopaedic Hospital, Faculty of Medicine Universitas Sebelas Maret, Surakarta, Indonesia. \\ 2Department of Orthopaedic and Traumatology, Siloam Denpasar Hospital, Denpasar, Bali, Indonesia. ${ }^{3}$ Department of Orthopaedic and Traumatology, OMNI Alam Sutera Hospital, Tangerang, Banten, Indonesia.}

\section{ABSTRACT}

Background: Discoid meniscus is a rare entity of knee pathology. The discoid meniscus can be encountered incidentally during a treatment of another knee pathology as an asymptomatic entity or can be a symptomatic pathology which warrants treatment.

Case Presentation : There were 8 cases of symptomatic discoid meniscus reported in this retrospective case series. The symptoms presented at age range 16-47 years old. Majority of the cases (6 of 8 ) are lateral discoid meniscus with female gender predominant. Complete type of discoid meniscus was also found in 6 of 8 cases. There were 5 cases of ruptured discoid meniscus, three of them needed repair.

Conclusion: Symptomatic discoid meniscus can be presented in a wide range of age of patients. We found female gender, discoid lateral meniscus, and complete type are the predominant pattern of discoid meniscus case presentation.

Keywords: knee; discoid meniscus; symptomatic

Level of Evidence: IV

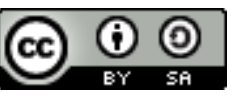

This is an open access article under the CC-BY-SA license.

\section{Article history:}

Submission

Revision

Accepted
: December 25th, 2020

: December 31 $1^{\text {st }}, 2020$

: January $4^{\text {th }}, 2021$
Corresponding Author:

Asep Santoso, MD.

Department of Orthopaedic and Traumatology, Prof. Dr. R.

Soeharso Orthopaedic Hospital, Jl. Jenderal Ahmad Yani,

Pabelan, Surakarta. 57162,

Email: asepsantoso@gmail.com 


\section{Introductions}

Discoid meniscus is a rare entity of knee pathology that occurs in only 3.2-4.8/100,000 patients. ${ }^{1,2}$ Discoid meniscus was first described by Young et al. in $1889 .{ }^{3}$ After that, the number of publications and reports about discoid meniscus cases have significantly increased in the literature. ${ }^{4}$ As an asymptomatic entity, the discoid meniscus can be encountered incidentally during a treatment of another knee pathology or can be a symptomatic pathology which warrants treatment. ${ }^{4,5}$ A discoid meniscus can occur in either medial, or lateral and both of the menisci. ${ }^{5,6,7}$ Furthermore, it also can occur in a ipsilateral or bilateral case. ${ }^{7,8}$

Several classification systems have been proposed in order to better understand about the spectrum of this pathology. ${ }^{4}$ Treatments for discoid meniscus are also varied, ranging from conservative, saucerization, excision, repair or combined procedures. ${ }^{9}$ Several countries have reported population-based studies on the demographics of discoid meniscus presentation. ${ }^{1,2,10,11}$ Our recent study aimed to evaluate the demographics, clinical presentation and treatment of discoid meniscus treated in our centers. To our knowledge, this is the first paper to describe about the profile of discoid meniscus cases from our country.

\section{Case Presentation}

This was a retrospective case series of patients with discoid meniscus treated in three centers in Indonesia. All included case were symptomatic cases. We collected data on demographics including: age, gender, symptoms, and durations of symptoms. We also evaluated the type of pathology including: medial or lateral meniscus involvement, unilaterality, concomitant congenital pathology and classification of the pathology according to the Watanabe classification (Figure 1). ${ }^{9}$ All of the cases were treated with arthroscopic surgical procedure. Type of treatment can be classified to partial meniscectomy, saucerization, total meniscectomy, repair or a combined procedure.
A total of 8 cases were included in this study. Discoid meniscus more commonly occurred in female patients with 7 of $8(87.5 \%)$ cases. The symptoms presented in the age range of $16-47$ years old. Discoid lateral meniscus was more commonly found with 6 of $8(75 \%)$ cases, while medial and both meniscus involvement were found with one case each. Complete type of discoid meniscus according to the Watanabe classification was found in 6 of 8 (75\%) cases, while the rest were incomplete type. The Wrisberg type of discoid meniscus was not found in our series. No concomitant congenital abnormality was found in our series.

Pain was the most common symptom in discoid meniscus which occurred in all patients of our series. Snapping knee was found in 5 of 8 cases with three of them which occurred in full knee extension position. Knee locking occurred in 4 of 8 $(50 \%)$ cases. Among four cases with the symptom of locking knee, only three cases were associated with ruptured discoid meniscus. We found 5 of 8 $(62.5 \%)$ of cases with a ruptured discoid meniscus. All patients received arthroscopy surgical treatment. Saucerization was performed to all of the cases. Among five cases of ruptured discoid meniscus, only three cases needed repair. Table 1 shows the summary of the cases.

Table 1. Summary of symptomatic discoid meniscus cases

\begin{tabular}{|c|c|c|c|c|c|c|c|}
\hline $\begin{array}{l}\text { No. } \\
\text { Cases }\end{array}$ & $\begin{array}{l}\text { Gender } \\
/ \mathrm{Age}\end{array}$ & 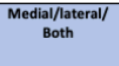 & $\begin{array}{c}\text { Watanabe } \\
\text { Classification }\end{array}$ & $\begin{array}{l}\text { Symptoms } \\
\text { and duration }\end{array}$ & Rupture & $\begin{array}{c}\text { Other } \\
\text { congentital } \\
\text { abnormality }\end{array}$ & Treatment \\
\hline 1 & F/16 vo & Lateral & $\begin{array}{c}\text { Complete } \\
\text { Type }\end{array}$ & $\begin{array}{c}\text { Pain, in } \\
\text { sarpping in } \\
\text { fullextension, }\end{array}$ & No & No & Saucerization \\
\hline 2 & $F / 33$ yo & Lateral & $\begin{array}{c}\text { Incomplete } \\
\text { Type }\end{array}$ & Pain, 3 months & Yes & No & Saucerization, Repair \\
\hline 3 & F/47 yo & Lateral & $\begin{array}{c}\text { Incomplete } \\
\text { Type }\end{array}$ & $\begin{array}{c}\text { Pain, } \\
\text { sanping, } \\
\text { locking, , } \\
\text { months }\end{array}$ & Yes & No & $\begin{array}{l}\text { Saucerization } \\
\end{array}$ \\
\hline 4 & F/26 yo & lateral & $\begin{array}{c}\text { Complete } \\
\text { type }\end{array}$ & $\begin{array}{l}\text { Pain, snapping } \\
\text { in fulu } \\
\text { extension, } \\
\text { years, }\end{array}$ & No & No & $\begin{array}{l}\text { Saucerization } \\
\end{array}$ \\
\hline 5 & F/20 yo & lateral & $\begin{array}{c}\text { Complete } \\
\text { Type }\end{array}$ & $\begin{array}{c}\text { Pain, snapping } \\
\text { if full } \\
\text { extension, } \\
\text { years }\end{array}$ & Yes & No & $\begin{array}{l}\text { Saucerization } \\
\end{array}$ \\
\hline 6 & F/17 yo & Both & $\begin{array}{c}\text { Complete } \\
\text { Type }\end{array}$ & $\begin{array}{c}\text { Yetars } \\
\text { Pain, } \\
\text { sanpoping, } \\
\text { Locking, } \\
\text { years } \\
\end{array}$ & No & No & Saucerization \\
\hline 7 & $F / 34$ yo & medial & $\begin{array}{c}\text { Complete } \\
\text { type }\end{array}$ & $\begin{array}{c}\text { Pain, locking } \\
\text { knee }\end{array}$ & Yes & No & Saucerization, Repair \\
\hline 8 & M/24yo & Lateral & $\begin{array}{c}\text { Complete } \\
\text { type }\end{array}$ & $\begin{array}{l}\text { Pain, locking } \\
\text { knee }\end{array}$ & Yes & No & Saucerization, Repair \\
\hline
\end{tabular}



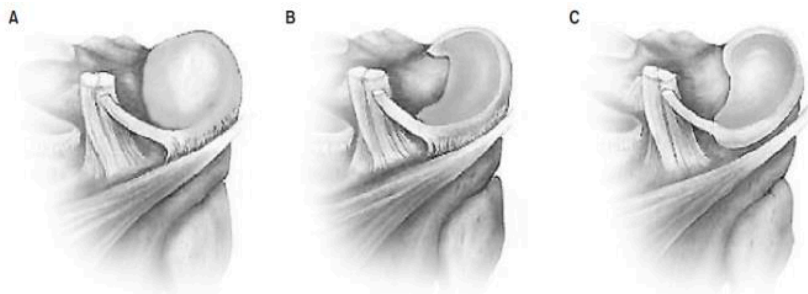

Figure 1. Classification of Discoid meniscus according to Watanabe et al (9).
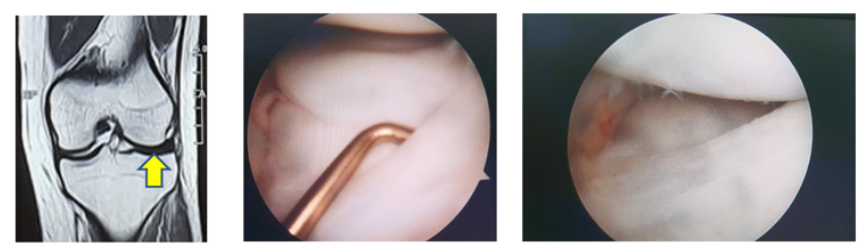

Figure 2. Case illustration of a female 16 years-old with Snapping knee in full extension position. A. Magnetic resonance image (MRI) finding (arrow); B. Intra-operative finding of incomplete discoid

lateral meniscus; C. Discoid lateral meniscus after saucerization
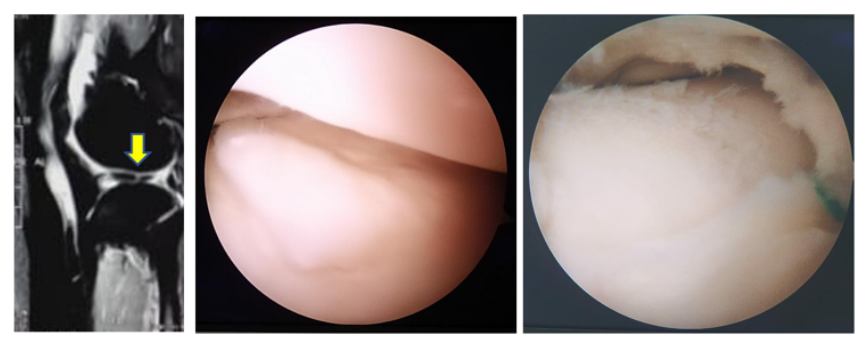

Figure 3. Case illustration of a female 33 years-old with painful knee without snapping/locking. A. MRI image showed a ruptured incomplete discoid lateral meniscus; B. Intraoperative finding; C. After saucerization and repair.
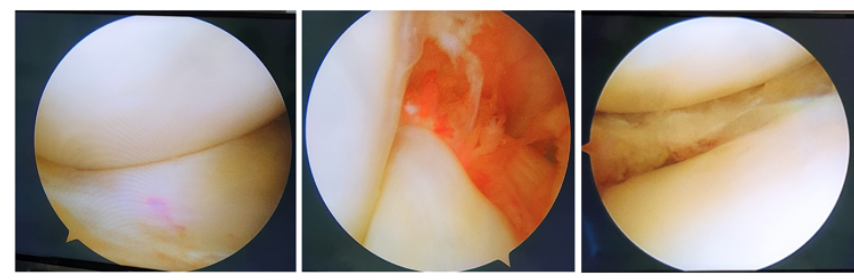

Figure 4. Case illustration of male 24 years-old with a painful knee with snapping and locking. A and $B$. Intra-operative finding of complete discoid lateral meniscus; C. After Saucerization
Discussion

The main purpose of this study was to review the demographics and the pattern of clinical presentation in symptomatic discoid meniscus. We found the age range of patients in this series was 16 to 47 years old. A previous population-based study in China showed that symptomatic discoid meniscus can be found within the age range from 3 to 80 years old..$^{11}$ The data showed that the age of presentation could be extremely wide from pediatric to elderly patients. Usually, most of the cases were found in younger (adolescent) patients with age range $15-18$ years old. ${ }^{1}$ We found 7 of 8 cases of symptomatic discoid meniscus were female gender. The finding was similar to a report by Chen et al. which found female patients outnumbered male patients with $69.6 \%$ versus $30.4 \%$, respectively. ${ }^{1}$ However, previous studies in China and US showed that the female versus male incidence of discoid meniscus is similar. ${ }^{1,6}$ The majority of discoid meniscus were found as symptomatic cases $(77.5 \%)$, while the rest was asymptomatic (22.5\%) [2]. The most common symptom of discoid meniscus was associated with a ruptured case, which occurred in up to $72 \%$ of the case. ${ }^{1}$

Regarding the type, the complete type of discoid meniscus was the most commonly found in our series with 6 of 8 cases. The findings were similar to a previous study by Chen et al. with $69.4 \%$ of cases which were complete type, followed by incomplete type with $30 \%$ and Wrisberg type with $0.6 \% .{ }^{11}$ Medial and both meniscus involvement is rare. ${ }^{7,12}$ Lateral meniscus cases are still the most common presented type of discoid meniscus. We found 6 of 8 cases were a lateral discoid meniscus. We also did not find any concomitant congenital abnormality in all of the cases.

Not all patients with discoid meniscus needed surgical treatment. A report by Grimm et al. reported that symptomatic discoid menisci were more likely to be operated on compared with asymptomatic discoid menisci ( $71 \%$ vs $14 \%$,). Further, they also reported that $95 \%$ of the surgeries were saucerization. ${ }^{2}$ All of the patients received saucerization in our recent series. We also found 5 of 8 cases were a ruptured discoid 
meniscus case. Although repair was only needed in three cases. Horizontal and bucket-handle are the most commonly type of tear in discoid meniscus cases. ${ }^{2}$ Chen et al. reported that $11.2 \%$ of discoid lateral meniscus also have concomitant ruptured medial meniscus. ${ }^{11}$ Sixty patients $(75.9 \%)$ received surgical treatment during the study period, including 49 (81.7\%) patients who underwent partial lateral meniscectomy and 11 (18.3\%) patients who underwent lateral meniscus repair in addition to saucerization. ${ }^{1}$

\section{Conclusions}

Symptomatic discoid meniscus can be presented in a wide range of age of patients. We found female gender, discoid lateral meniscus, and complete type are the predominant pattern of case presentation.

\section{Conflict of Interest}

The authors affirm no conflict of interest in this study

Acknowledgement

None

\section{References}

1. Sabbag OD, Hevesi $M$, Sanders TL, Camp CL, Dahm DL, Levy BA, Stuart MJ, Krych AJ. Incidence and treatment trends of symptomatic discoid lateral menisci: an 18year population-based study. Orthop J Sports Med. 2018 Sep 24;6(9):2325967118797886.

2. Grimm NL, Pace JL, Levy BJ, Arthur D, Portman $M$, Solomito MJ, Weiss JM. Demographics and epidemiology of discoid menisci of the knee: analysis of a large regional insurance database. Orthop J Sports Med. $2020 \quad$ Sep 17;8(9):2325967120950669.

3. Young RB, Cleland J, MacKay JY: The external semi-lunar cartilage as a complete disc. Memoirs and Memoranda in
Anatomy. London, Williams and Norgate 1979, 1:179-80.

4. Saavedra $M$, Sepúlveda $M$, Jesús Tuca $M$, Birrer E. Discoid meniscus: current concepts. EFORT Open Rev. 2020 Aug 1;5(7):371-379.

5. Sevillano-Perez E, Espejo-Reina A, EspejoReina MJ. Symptomatic bilateral torn discoid medial meniscus treated with saucerization and suture. Case Rep Orthop. 2016;2016:8487194.

6. Sabbag OD, Hevesi $M$, Sanders $T L$, Camp CL, Dahm DL, Levy BA, Stuart MJ, Krych AJ. High rate of recurrent meniscal tear and lateral compartment osteoarthritis in patients treated for symptomatic lateral discoid meniscus: a population-based study. Orthop J Sports Med. 2019 Jul 19;7(7):2325967119856284.

7. Kim SJ, Lubis AM. Medial and lateral discoid menisci: a case report. Sports Med Arthrosc Rehabil Ther Technol. 2010 Aug 23;2:21.

8. Yang $X$, Shao D. Bilateral discoid medial meniscus: two case reports. Medicine (Baltimore). 2019 Apr;98(15):e15182.

9. Kim JG, Han SW, Lee DH. Diagnosis and treatment of discoid meniscus. Knee Surg Relat Res. 2016 Dec 1;28(4):255-262.

10. Mutlu S, Mutlu H, Mutlu B, Guler O, Duymus TM. Symptoms of discoid lateral menisci. J Orthop. 2014 Jul 18;11(4):180-2.

11. Chen G, Zhang Z, Li J. Symptomatic discoid lateral meniscus: a clinical and arthroscopic study in a Chinese population. BMC Musculoskelet Disord. 2016 Aug 5;17:329. 